\title{
Diffusive Transport of Dissolved Gases in Potential Concretes for Nuclear Waste Disposal
}

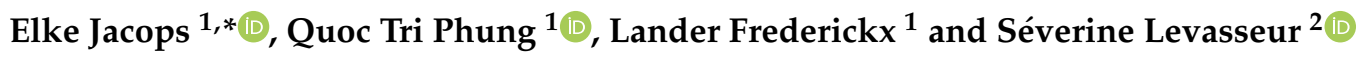 \\ 1 SCK CEN, 2400 Mol, Belgium; quoc.tri.phung@sckcen.be (Q.T.P.); lander.frederickx@sckcen.be (L.F.) \\ 2 ONDRAF/NIRAS, 1210 Brussels, Belgium; S.Levasseur@nirond.be \\ * Correspondence: elke.jacops@sckcen.be
}

Citation: Jacops, E.; Phung, Q.T.;

Frederickx, L.; Levasseur, S. Diffusive Transport of Dissolved Gases in Potential Concretes for Nuclear Waste Disposal. Sustainability 2021, 13, 10007. https://doi.org/10.3390/ su131810007

Academic Editor: Tomonobu Senjyu

Received: 14 July 2021

Accepted: 30 August 2021

Published: 7 September 2021

Publisher's Note: MDPI stays neutral with regard to jurisdictional claims in published maps and institutional affiliations.

Copyright: (c) 2021 by the authors. Licensee MDPI, Basel, Switzerland. This article is an open access article distributed under the terms and conditions of the Creative Commons Attribution (CC BY) license (https:// creativecommons.org/licenses/by/ $4.0 /)$.

\begin{abstract}
In many countries, the preferred option for the long-term management of high- and intermediate level radioactive waste and spent fuel is final disposal in a geological repository. In this geological repository, the generation of gas will be unavoidable. In order to make a correct balance between gas generation and dissipation by diffusion, knowledge of the diffusion coefficients of gases in the host rock and the engineered barriers is essential. Currently, diffusion coefficients for the Boom Clay, a potential Belgian host rock, are available, but the diffusion coefficients for gases in the engineered concrete barriers are still lacking. Therefore, diffusion experiments with dissolved gases were performed on two concrete-based barrier materials considered in the current Belgian disposal concept, by using the double through-diffusion technique for dissolved gases, which was developed in 2008 by SCK CEN. Diffusion measurements were performed with four gases including helium, neon, methane and ethane. Information on the microstructure of the materials (e.g., pore size distribution) was obtained by combining $\mathrm{N}_{2}$-adsorption, mercury intrusion porosimetry (MIP), scanning electron microscopy (SEM) and water sorptivity measurements. A comparison was made with data obtained from cement-based samples (intact and degraded), and the validity of existing predictive models was investigated.
\end{abstract}

Keywords: gas diffusion; concrete; engineered barrier; microstructure; nuclear disposal

\section{Introduction}

The preferred option adopted by many countries for the long-term management of high- and intermediate-level radioactive waste and/or spent fuel is its disposal in a geological repository, in which a multi-barrier system, combining natural host rock and engineered barriers, is adopted. In Belgium, no formal decision on a host formation has been taken yet, but for R\&D purposes, the Belgian radioactive waste management organization ONDRAF/NIRAS considers Boom Clay as one of the potential natural barriers for a geological disposal facility in poorly indurated plastic clays. Boom Clay has favorable properties such as a low hydraulic conductivity [1], a high sorption capacity for many radionuclides $[2,3]$ and self-sealing properties $[4,5]$. In a plastic clay such as the Boom Clay, the use of concrete is difficult to avoid, and cement-based materials will be an essential part of the engineered barrier system (EBS) (Figure 1). The concept which includes the cement-based barriers is referred to as the "supercontainer concept" [6]. The three main cement-based components which can be distinguished in this "supercontainer concept" are: the disposal supercontainer, the backfill and the gallery lining. The supercontainer is a very large concrete container which will contain certain types of waste. These supercontainers will be placed in the disposal galleries. The disposal galleries are covered with concrete wedge blocks (named "lining") to ensure the mechanical stability. In a last stage, the remaining voids will be filled up with a cement-based backfill. The most important role of cement-based backfill is to help create beneficial conditions for the integrity of the waste package (steel corrosion) because of its high $\mathrm{pH}$ buffering capacity for a very long period. 


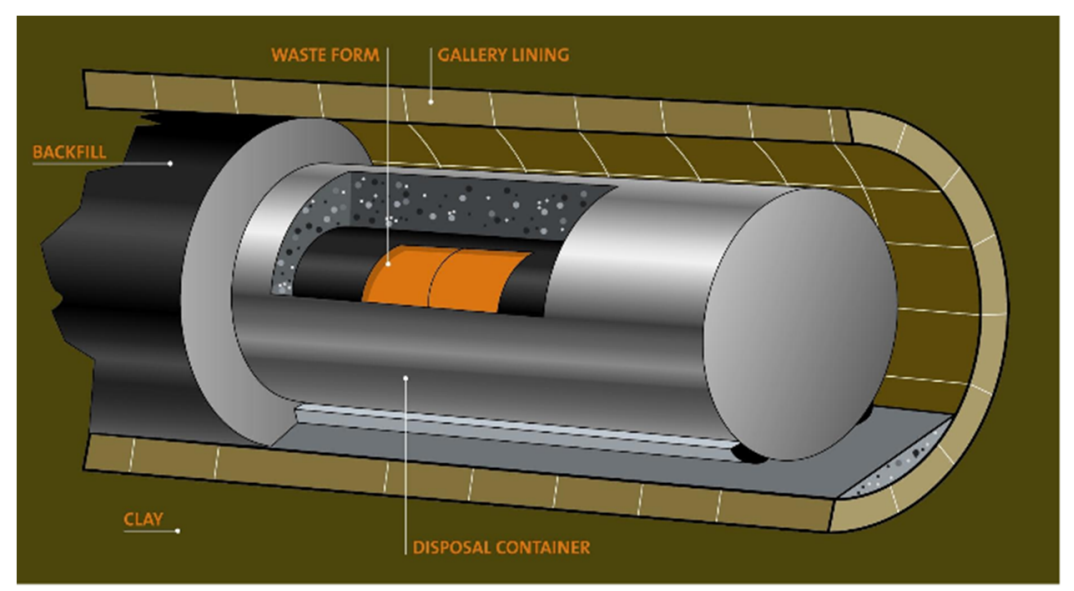

Figure 1. Schematic overview of the supercontainer disposal concept in Boom Clay [7] (C) ONDRAF/NIRAS.

Within a repository, the generation of gases is unavoidable [8-11]. Gas can be produced by different mechanisms: anaerobic corrosion of waste and packages, radiolysis of water and organic compounds in the waste packages and microbial degradation of various organic waste streams. In a first stage, the generated gas will dissolve in the pore water and will be transported away by diffusion. When the rate of gas generation exceeds the capacity of diffusive transport, the available water will become oversaturated with gas and a free gas phase might form. When more and more gas is generated, the pressure in the free gas phase will increase and might finally affect the safety functions of the different barriers around the waste. Whether the disposal system will ever be subjected to such high gas pressures depends on the balance between gas generation and gas dissipation. Therefore, one should understand both the gas generation and the gas dissipation process. Because of the low permeability and small hydraulic gradient, transport of gases/solutes in the Boom Clay and engineered barriers is diffusion-driven, and the rate of diffusion of a gas/solute is described by its diffusion coefficient. Therefore, in order to make a correct balance between gas generation and gas dissipation by diffusion, knowledge of diffusion coefficients of relevant gases is essential $[12,13]$. To measure the diffusion coefficients of dissolved gases in Boom Clay, a versatile technique was developed $[13,14]$ based on double through-diffusion. This technique allows for measuring the diffusion coefficients of two dissolved gases simultaneously with high precision. With this method, diffusion coefficients have been obtained for various dissolved gases ( $\left.\mathrm{He}, \mathrm{Ne}, \mathrm{H}_{2}, \mathrm{CH}_{4}, \mathrm{Xe}, \mathrm{C}_{2} \mathrm{H}_{6}\right)$ in sands and clayey materials (Boom Clay, Eigenbilzen Sands, Callovo-Oxfordian Clay, Opalinus Clay, bentonite) [13-18].

When gas is generated in the waste and its packages, it will first be in contact with the engineered barrier system and only in a later stage with the host rock. The diffusivity of gas is an important parameter for characterizing and assessing the long-term performance of concrete as it could affect some chemical degradation phenomena such as carbonation $[19,20]$ and calcium leaching [21].

The available setup of [14] was designed to measure diffusion coefficients in swelling clay materials and could not, as such, be used for cement-based systems and was therefore modified by Phung [22]. Over the last decade, Phung et al. [23] performed several diffusion experiments with dissolved gases on cement-based materials in the framework of concrete durability studies. As the aim was to understand the impact of the potential degradation processes (leaching and carbonation) on material properties, "simple" systems, consisting of only cement, water and limestone filler were used. In Ref. [23], diffusion data are available for samples with various water/cement $(\mathrm{w} / \mathrm{c})$ or water/powder $(\mathrm{w} / \mathrm{p})$ ratios and a different portion of limestone filler ( $\mathrm{LF} \%$ ). As "simple systems" were studied, there was no direct link to materials which could potentially be used in a repository. 
Thus, the gas diffusion data for concrete components of the engineered barrier system were not yet available. Therefore, this study focuses on obtaining diffusion coefficients of two potential engineered barrier materials (supercontainer and gallery lining) for four different gases with different sizes $\left(\mathrm{He}, \mathrm{Ne}, \mathrm{CH}_{4}\right.$ and $\left.\mathrm{C}_{2} \mathrm{H}_{6}\right)$. The diffusion study is complemented with the characterisation of the microstructure (e.g., pore size distribution) of the studied materials in order to further set up models that can estimate diffusivity from the microstructural properties of the investigated materials.

\section{Materials and Methods}

\subsection{Materials}

Two different types of cement-based materials have been used in this study: samples from the gallery lining and samples from the supercontainer. The lining was made from high strength concrete (28-day compressive strength of $88 \mathrm{MPa}$ [24]). The samples from the lining have been drilled from wedge blocks, which were leftovers from the installation of the connecting gallery, stored at ESV EURIDICE (a European Underground Research Infrastructure for DIsposal of nuclear waste in Clay Environment, located in Mol, Belgium). The samples from the supercontainer have been cored by drilling from an existing half scale prototype version of the supercontainers, located at ESV EURIDICE. Supercontainer concrete is self-compacting concrete made from cement CEM I with a 28-day compressive strength of $60 \mathrm{MPa}$. Other mechanical properties can be found in [25].

The compositions of lining and supercontainer concretes are shown in Table 1 [26]. Note that this study is exploratory, and the materials used in this study might differ from those used in the final disposal concept. Nevertheless, they can be considered as indicative for properties of high-performance concrete.

Table 1. Mix compositions of lining concrete: SP—Superplasticizer, LF-limestone filler.

\begin{tabular}{|c|c|c|c|c|c|c|c|c|}
\hline \multirow{2}{*}{$\begin{array}{l}\text { For } 1 \mathrm{~m}^{3} \\
\text { Concrete }\end{array}$} & \multirow{2}{*}{$\begin{array}{l}\text { Cement } \\
{[\mathrm{kg}]}\end{array}$} & \multirow{2}{*}{$\begin{array}{l}\text { Fly Ash } \\
\text { [kg] }\end{array}$} & \multirow{2}{*}{$\begin{array}{c}\text { Coarse Aggregates } \\
{[\mathrm{kg}]}\end{array}$} & \multirow{2}{*}{$\begin{array}{c}\text { Fine Aggregates } \\
{[\mathrm{kg}]}\end{array}$} & \multicolumn{3}{|c|}{ Admixture } & \multirow{2}{*}{$\begin{array}{c}\text { Water } \\
\text { [L] }\end{array}$} \\
\hline & & & & & SP $[L]$ & LF [kg] & $\mu$-Silica [kg] & \\
\hline Lining concrete & 335 (CEM I) & 115 & 1252 & 540 & 4.5 & - & 90 & 135 \\
\hline Supercontainer & 350 (CEM I) & - & 886 & 840 & 8 & 100 & - & 175 \\
\hline
\end{tabular}

\subsection{Methods}

\subsubsection{Sample Embedding and Saturation}

Embedding and saturation of the samples are essential steps before transport properties measurements, and they have been described in detail in the work of Phung [22].

The core samples are embedded in resin in a custom-made permeability cell. This cell consists of an outer steel reinforcement cylinder wrapping an inner cylindrical ring of polycarbonate. The steel part allows for applying a high-pressure gradient, as an outer part made of polycarbonate would only withstand low pressures. The polycarbonate inner part enables a visual check of the contact between the resin and the sample. In order to improve friction between the inner part and the sample, grooves were created on the surface of the inner part. Good fitting of the inner and outer parts was obtained by their conical shapes. The top and bottom lids were also made of steel. Circular grooves are foreseen to emplace O-rings to ensure proper sealing. The inner surfaces of the lids had a special design with a groove network to distribute water equally over the surface of the sample. Cellulose membrane filters with high water flow rate were placed between the sample sides and the lids to prevent particle transport and improve the distribution of water. Quick couplings helped to expel air and to fill all connecting tubes before measuring the permeability and diffusivity.

Embedding occurs by using a resin. The choice of an effective resin is crucial to avoid leakage around the side of the sample. The resin should have low viscosity, good contact with the polycarbonate and the cement-based material, high strength, transparency and low heat generation during embedding. For the samples used in this study, Sika ${ }^{\circledR}$ Injection-451 
(Sika Services AG $(\mathrm{CH})$, Zürich, Switzerland) was selected as the most optimal choice. Polymerization takes, in general, $24 \mathrm{~h}$.

The samples were afterwards saturated in lime water under vacuum conditions for $3 \mathrm{~h}$ and at atmospheric pressure for another $20 \mathrm{~h}$. Once the sample was fully saturated, both lids were placed on the cell, the O-rings were put in place, and the assembled permeability cell was compacted by using screws and bolts. The mounted permeability cell was then ready for further measurements (hydraulic conductivity and diffusivity).

\subsubsection{Hydraulic Conductivity Measurement}

Hydraulic conductivity is generally obtained by measuring the water flow rate at a constant pressure gradient. However, for low permeability materials, this method is not optimal as it is too slow and not accurate enough. Therefore, in this study, we used a constant flow method described in [22]. A pressure gradient of 5 to 10 bar was applied by controlling the pressure at both sides of a saturated cement-based core embedded in a permeability cell (Figure 2). When the flow reaches almost steady state, the constant pressure mode was changed to the constant flow mode. Instead of measuring the flow rate using existing direct techniques, the pressure was measured, which is much more accurate than measuring flow rate. The pressure and water flow were controlled by precise syringe pumps.
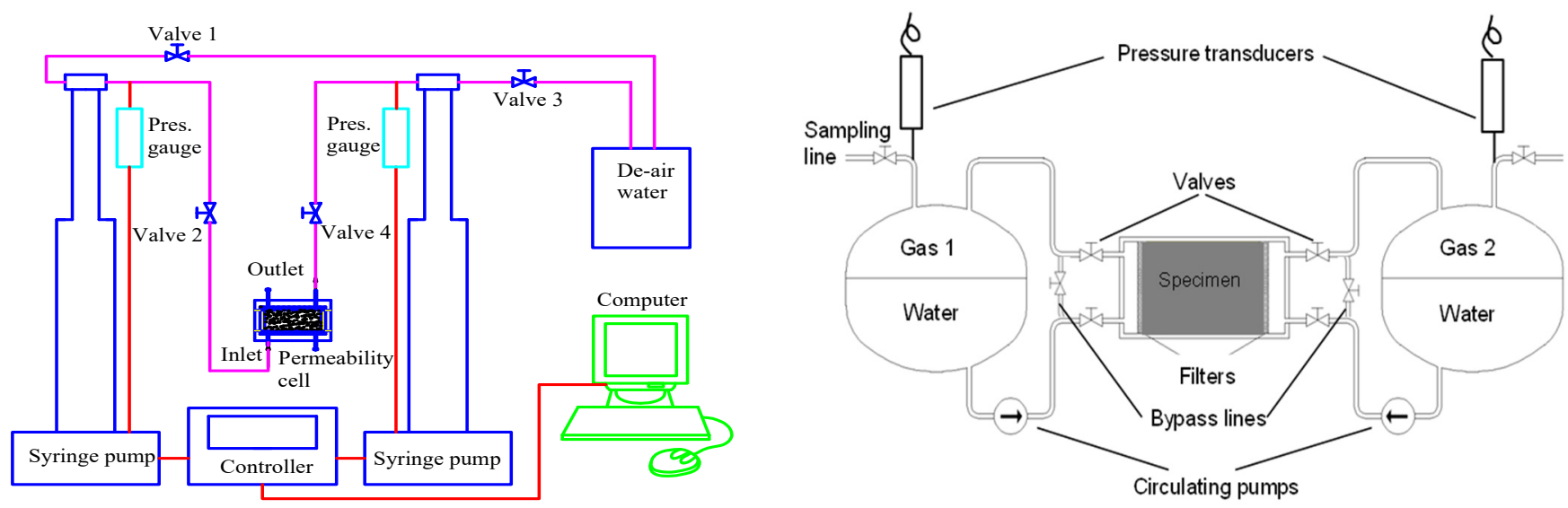

Figure 2. Schematic overview of the setups used to measure hydraulic conductivity (left) and diffusivity of dissolved gases (right) (adapted from $[9,20]$ ).

\subsubsection{Measuring Diffusion of Dissolved Gases}

The methodology of through-diffusion experiments has been described in detail in [14]. Only the main aspects are repeated here. The basis is the double through-diffusion technique with two water reservoirs with dissolved gases placed on opposite sides of a saturated test core (Figure 2). The core was sealed in a permeability cell (constant volume) and was connected via filter plates (at both sides) to two water vessels (filled each with circa $500 \mathrm{~mL}$ oxygen-free demineralised water). Both water vessels were pressurized, each with a different gas at the same total pressure (circa $500 \mathrm{~mL}$ gas at $1 \mathrm{MPa}$ ). In this way no advective flux could occur and the sample remained fully water saturated. According to Henry's law, equilibrium was obtained between the free gas in the gas phase and the dissolved gas in the water. The water at both sides was then circulated over the filters, which were in contact with the sample, allowing the dissolved gases to diffuse from the high concentration side, through the sample, towards the low concentration reservoir on the opposing side. The change in gas composition in both reservoirs was measured as a function of time by gas chromatography.

Sampling of the gas phase was performed on a regular basis (generally once per 2 weeks) until 10 data points were obtained in the regime of approximately constant outlet flux of the diffusion process. The gas composition was analysed with a CG4 Compact GC 
(Interscience, Breda, The Netherlands), using EZChrom software. The experiment was performed in a temperature-controlled room $\left(21 \pm 2{ }^{\circ} \mathrm{C}\right)$.

Two series of diffusion experiments were performed, subsequently using combinations of $\mathrm{He}$ and $\mathrm{CH}_{4}$, and $\mathrm{Ne}$ and $\mathrm{C}_{2} \mathrm{H}_{6}$.

\subsubsection{Estimation of Diffusion Coefficients from Diffusion Experiment Results}

Two transport parameters can be obtained from diffusion experiments: the apparent diffusion coefficient $D_{a p p}\left(\mathrm{~m}^{2} / \mathrm{s}\right)$ and the capacity factor $\eta R$, which is the product of the accessible porosity $\eta$ (dimensionless) and the retardation factor $R$ (dimensionless). The capacity factor is the ratio of the tracer concentration $C_{b}$ in the bulk sample and the corresponding concentration $C$ in the pore fluid (solution): $\eta R=C_{\mathrm{b}} / C$.

From these two basic parameters, one can calculate the effective diffusion coefficient $D_{\text {eff }}\left(\mathrm{m}^{2} / \mathrm{s}\right)$ as:

$$
D_{e f f}=\eta R D_{a p p}
$$

and, assuming the accessible porosity equals the total porosity $\eta_{t o t}$, the pore diffusion coefficient $D_{p}\left(\mathrm{~m}^{2} / \mathrm{s}\right)$ is defined as:

$$
D_{p}=R D_{a p p}
$$

For unretarded species, the retardation factor is generally put equal to one $(R=1)$, leading to $D_{a p p}=D_{p}$ and a capacity factor equal to the total porosity $\eta_{\text {tot }}$.

These diffusion equations are fitted to the results of the diffusion experiments by optimizing equations in COMSOL Multiphysics software with the appropriate boundary and initial conditions. The gas diffusion model in COMSOL $[13,14]$ takes into account changing boundary conditions such as the pressure reduction in both vessels due to sampling.

A through-diffusion experiment typically allows fitting two parameters, which are the apparent diffusion coefficient $D_{a p p}$ and the capacity factor $\eta R$. For gases, an alternative fit strategy is possible: when assuming no retardation or interaction and thus $R=1$, only $D_{a p p}$ is estimated and $\eta R$ is a constant equal to the total porosity (which is either measured or estimated). In many gas through-diffusion experiments where the (quasi) stationary state is reached very fast, a nearly total correlation is observed between the capacity factor, the apparent diffusion coefficient and the initial concentration. Because of this correlation, only the effective diffusion coefficient can be determined, and a one-parameter estimate is the only option. All gas diffusion coefficients, reported in this paper, are obtained from a one-parameter estimate.

\subsubsection{Measuring Water Sorptivity}

Sorptivity is a measure of the capacity of the medium to absorb or desorb liquid by capillarity [27] calculated as follows:

$$
I=\frac{W}{A}=S \sqrt{t}+I_{0}
$$

where $I=$ cumulative water absorption on tested surface $\left(\mathrm{mm}^{3} / \mathrm{mm}^{2}\right) ; W=$ volume of water absorption $\left(\mathrm{mm}^{3}\right) ; A=$ tested surface $\left(\mathrm{mm}^{2}\right) ; t=$ time variable $(\mathrm{min}) ; S=$ sorption coefficient $\left(\mathrm{mm} / \mathrm{min}^{1 / 2}\right)$; and $I_{0}=$ initial water absorption $\left(\mathrm{mm}^{3} / \mathrm{mm}^{2}\right)$.

A water sorptivity test is a unidirectional water absorption test, in which one side of a dried test specimen is in contact with water. All other sides are made impermeable to water (e.g., by coating or using tape). After making contact between sample and water, the mass change over time is registered. At the end of the experiment, the cumulative mass increase of the tested specimen at each measured time interval is divided by the area of the exposed side and plotted against the square root of time. Typically, a small positive intercept is observed on the $y$-axis, which is attributed to the initial filling of pores on the exposed surface. The sorption coefficient $S$ is directly derived from the slope of $I$ vs. $\sqrt{t}$ curve. The used procedure is modified from ASTM C1585-20, and modification includes the drying 
of the samples until stable mass is reached. Furthermore, a continuous measurement of mass change over time is possible, which improves the accuracy of mass measurement by avoiding taking the samples out to measure the mass regularly (as in ASTM C1585-20).

\subsubsection{Measurement of Water-Accessible Porosity}

The volume of water-accessible pore space of the samples was calculated from the oven dry mass $\left(m_{0}\right)$ after drying at $110^{\circ} \mathrm{C}$ for $24 \mathrm{~h}$, the water-saturated mass after immersion for $48 \mathrm{~h}$ and boiling for $5 \mathrm{~h}\left(m_{\text {sat }}\right)$ and the immersed apparent mass after suspending the sample on a wire in water $\left(m_{\text {app }}\right)$. The following equation was used:

$$
\text { Water porosity }(\%)=\frac{m_{\text {sat }}-m_{o}}{m_{\text {sat }}-m_{\text {app }}} \times 100
$$

\subsubsection{Mercury Intrusion Porosimetry (MIP)}

Prior to the MIP analysis, the samples were crushed with a hammer and chisel and freeze dried. Mercury injection porosimetry was performed at KU Leuven, Belgium, using an AutoPore IV 9500 mercury porosimeter. Mercury was injected up to a pressure of $200 \mathrm{MPa}$, and the pressure versus the injected volume of mercury was recorded.

Mercury is a non-wetting fluid and will not spontaneously flow into the pores by capillary action. It will only enter a pore when the resisting force is overcome. For a pore with a certain diameter, a certain pressure has to be exerted to overcome this resisting force. This relation between pressure and pore diameter is described by the Washburn equation [28]. By registering the pressure versus the intruded volume, and by applying the Washburn equation, the pore size distribution can be calculated.

\subsection{8. $\mathrm{N}_{2}$ adsorption Measurements: Specific Surface Area and Pore Size Distribution}

The specific surface area was measured by nitrogen adsorption at $77 \mathrm{~K}$ in a Gemini Surface Area Analyser (Micromeritics), using the Brunauer-Emmett-Teller theory [29]. Prior to the measurement, a sample mass of around $3 \mathrm{~g}$ was degassed at $110{ }^{\circ} \mathrm{C}$. Next, the pressure of $\mathrm{N}_{2}$ was gradually increased, and the amount of adsorbed gas was measured as a function of the relative pressure, which allows for plotting the adsorption isotherm.

Pore size distributions have been determined, using both the Barrett, Joyner and Halenda (BJH) [30] and the Dubinnin-Astakov [31] theories, which allows a reliable determination of the pore size distribution from $1.5 \mathrm{~nm}$ up to $250 \mathrm{~nm}$.

\subsubsection{Analysis of the Microstructure and Porosity by SEM Imaging}

Cubic samples of $1 \mathrm{~cm}^{3}$ were sawed and subsequently embedded in an Epofix resin. The embedded samples were then polished with the Struers Tegramin-30 device in a stepby-step process in which the grit of the polishing plate was reduced to $1 \mu \mathrm{m}$. Diamond paste was used for lubricating the samples during polishing. The polished samples were imaged with a Phenom Tabletop scanning electron microscope at a magnification of $500 \times$ and a voltage of $15 \mathrm{kV}$.

2.2.10. Obtaining a Pore Size Distribution from the Combination of MIP, $\mathrm{N}_{2}$-Adsorption and SEM Imaging

The SEM images were segmented in the Fiji software suite based on their grey level histogram to distinguish the pores from the rest of the material. The area of the individual pores was determined and processed to obtain a pore size distribution for each image. Due to the limited resolution of SEM, the calculated pore size distributions are only a part of the true pore size distribution of the sample. Therefore, the smaller pore size information can be obtained from MIP and $\mathrm{N}_{2}$-adsoprtion techniques. The gel pores ( $\mathrm{nm}$ size) are difficultly measured by MIP for normal applied pressure range. $\mathrm{N}_{2}$-adsorption is able to provide pore structure information in a smaller range compared to MIP technique. Therefore, we applied a method to combine these 3 techniques proposed in [32] in order to obtain a comprehensive picture on pore structures of how the concretes affect the diffusion properties. 


\section{Results and Discussion}

\subsection{Microstuctures and Water Sorptivity of Lining and Supercontainer Concretes}

The microstructural properties of lining and supercontainer concretes measured by $\mathrm{N}_{2-}$ adsoption are shown in Table 2. One can clearly observe a much denser microstructure for the lining concrete sample with a lower cumulative pore volume of $8.12 \mathrm{~mm}^{3} / \mathrm{g}$, compared to $20.68 \mathrm{~mm}^{3} / \mathrm{g}$ of the supercontainer. The specific surface area (SSA) obtained by the Brunauer-Emmett-Teller (BET) and t-plot methods are also threefold for the supercontainer compared to the ones of lining concrete. The amount of micropores $(<2 \mathrm{~nm}$ [33]) is very limited for both concretes. However, it is interesting to observe that the micropore volume of the lining concrete is larger than the supercontainer concrete, showing a higher micropore SSA, despite a lower total pore volume.

Table 2. Microstructural properties of supercontainer and lining concretes characterized by $\mathrm{N}_{2}$-adsoprtion.

\begin{tabular}{cccccc}
\hline Sample & $\mathbf{S S A}_{\mathbf{B E T}}\left(\mathbf{m}^{2} / \mathbf{g}\right)$ & $\mathbf{S S A}_{\mathrm{t}-\mathrm{plot}}\left(\mathbf{m}^{2} / \mathbf{g}\right)$ & $\mathbf{S S A}_{\mu \text { pore }}\left(\mathbf{m}^{2} / \mathbf{g}\right)$ & $\begin{array}{c}\text { Cumulative Pore } \\
\text { Volume }\left(\mathbf{m m}^{3} / \mathbf{g}\right)\end{array}$ & $\begin{array}{c}\text { Cumulative Micropore } \\
\text { Volume }\left(\mathbf{m m}^{3} / \mathbf{g}\right)\end{array}$ \\
\hline Lining concrete & 1.9 & 1.5 & 0.4 & 8.1 & 0.2 \\
Supercontainer & 4.7 & 4.4 & 0.2 & 20.7 & 0.1 \\
\hline
\end{tabular}

Figure 3 (top) shows the cumulative pore volume and pore size distribution obtained from adsorption branch using $\mathrm{BJH}$ method of lining and supercontainer concretes obtained by $\mathrm{N}_{2}$-adsoption measurements. The critical pore diameter of supercontainer concrete can be observed of about $20 \mathrm{~nm}$, while no peak for the critical pore size of lining concrete is found.
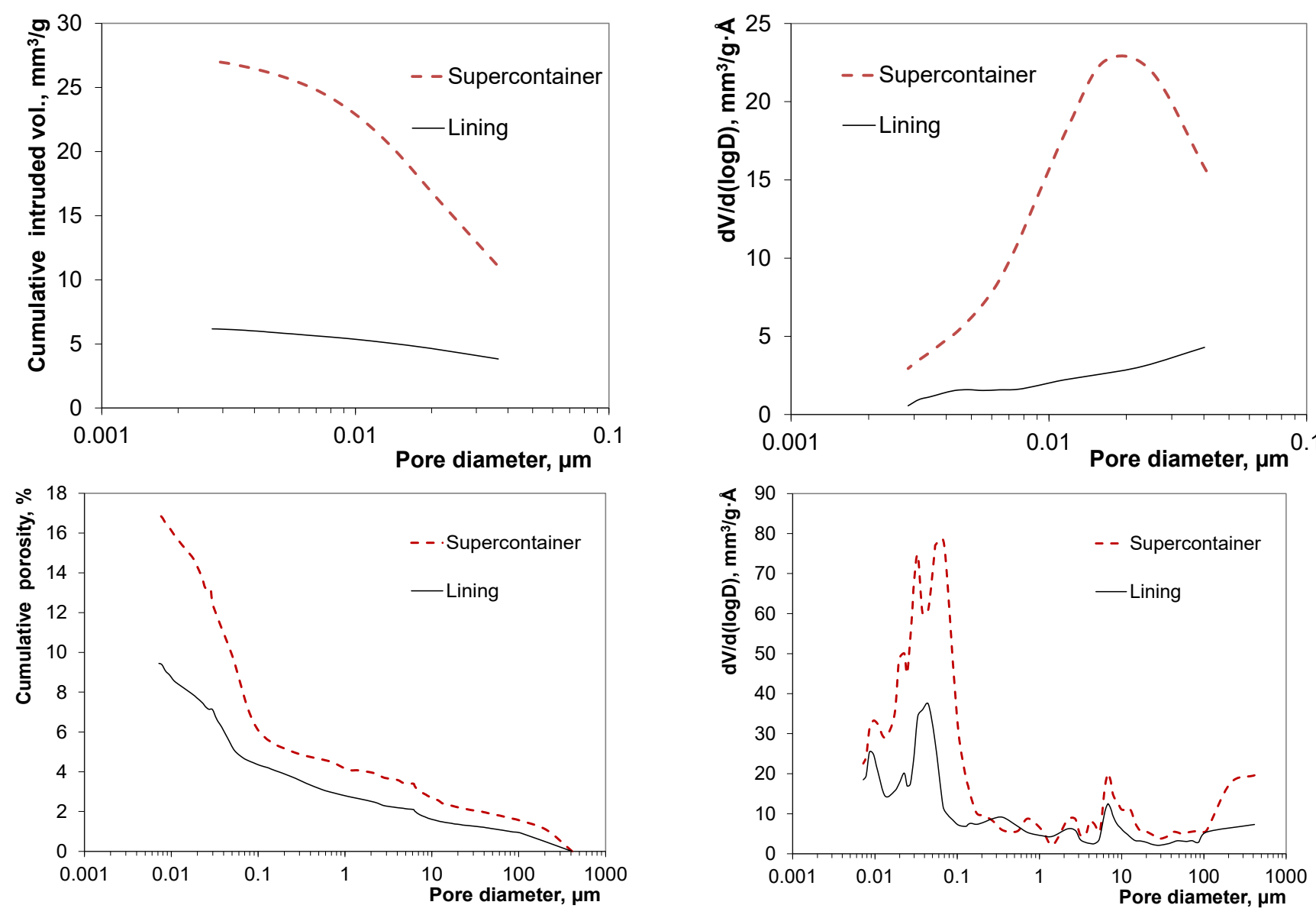

Figure 3. Cumulative pore volume and pore size distribution of supercontainer and lining concretes obtained by $\mathrm{N}_{2}$ adsorption (top) and MIP (bottom). 
Figure 3 (bottom) also shows the cumulative porosity and pore size distribution measured by MIP. It again shows a more porous structure for supercontainer concrete with higher cumulative porosity (17\% compared to $9.7 \%$ for lining concrete). The MIP pore size distribution shows that most of the pores of both the lining and supercontainer concretes distribute in the range 30 to $90 \mathrm{~nm}$. A small pore fraction at around $10 \mu \mathrm{m}$ is also observed, which could be attributed to the air voids or micro cracks presented in concretes.

In order to obtain more information at the micro scale, the SEM images were segmented and analyzed, as shown in Figure 4, with a SEM image of supercontainer concrete. The original SEM image was segmented to obtain a binary image containing pore and solid phases. The segmented image was then subjected to pore size measuring and counting in order to calculate the cumulative porosity and pore size distribution. Note that in order to obtain a representative manner, a set of around 10 SEM images was analyzed and the average microstructural properties were then calculated. As seen in Figure 4, most of the pores distribute around $10 \mu \mathrm{m}$, which is consistent with MIP measurement. However, the pore fraction in this case is much higher than the one determined by MIP.
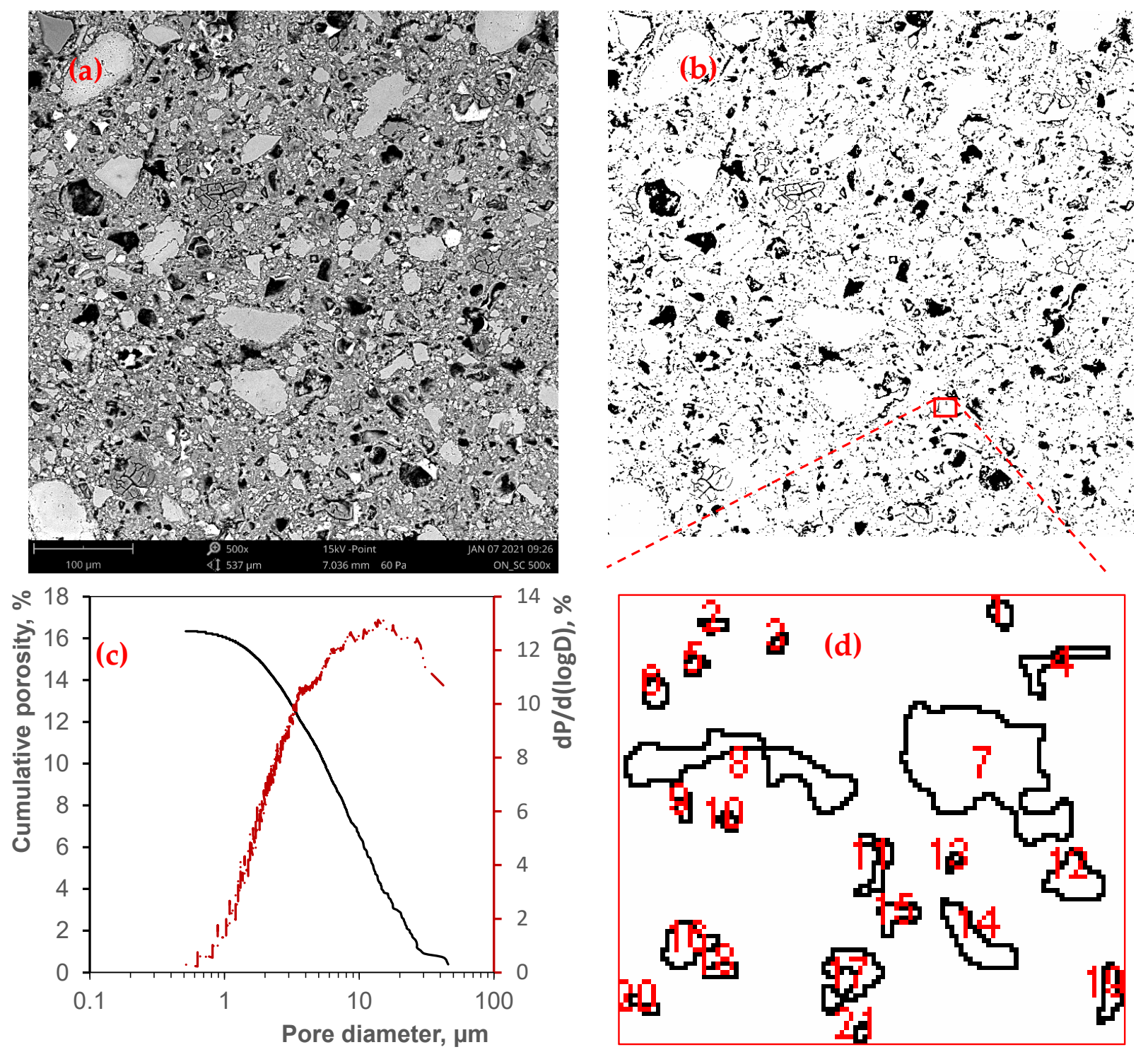

Figure 4. An example of SEM imaging analysis procedure to obtain the pore size distribution for supercontainer concrete: (a) original SEM image, (b) binary segmented image (black = pore), (c) SEM cumulative porosity and pore size distribution and (d) an example of pore size measuring and counting, in which the different pores are numbered (1 to 21). 
Applying a combination of MIP, $\mathrm{N}_{2}$-adsorption and SEM measurements allows us to obtain a full range of pore size distribution from $2 \mathrm{~nm}$ to $50 \mu \mathrm{m}$, as shown in Figure 5. In this study, the pores with size in range $10 \mathrm{~nm}$ to $1 \mu \mathrm{m}$ were characterized by MIP, while the smaller and larger pores were obtained by $\mathrm{N}_{2}$-adsorption and SEM, respectively. Note that the measurements were done on the specimens without coarse aggregates. Therefore, a normalization step is needed to estimate the pore size distribution of the samples with coarse aggregates by taking into account its volume fraction in the concretes. Figure 5 shows both pore size distribution for mortar (without coarse aggregate) and concrete levels. It can be seen that the coarse aggregates significantly contribute to the pore size distribution and the cumulative porosity. The cumulative porosity is almost double for both lining and supercontainer concretes if the coarse aggregate phase is not taken into account.

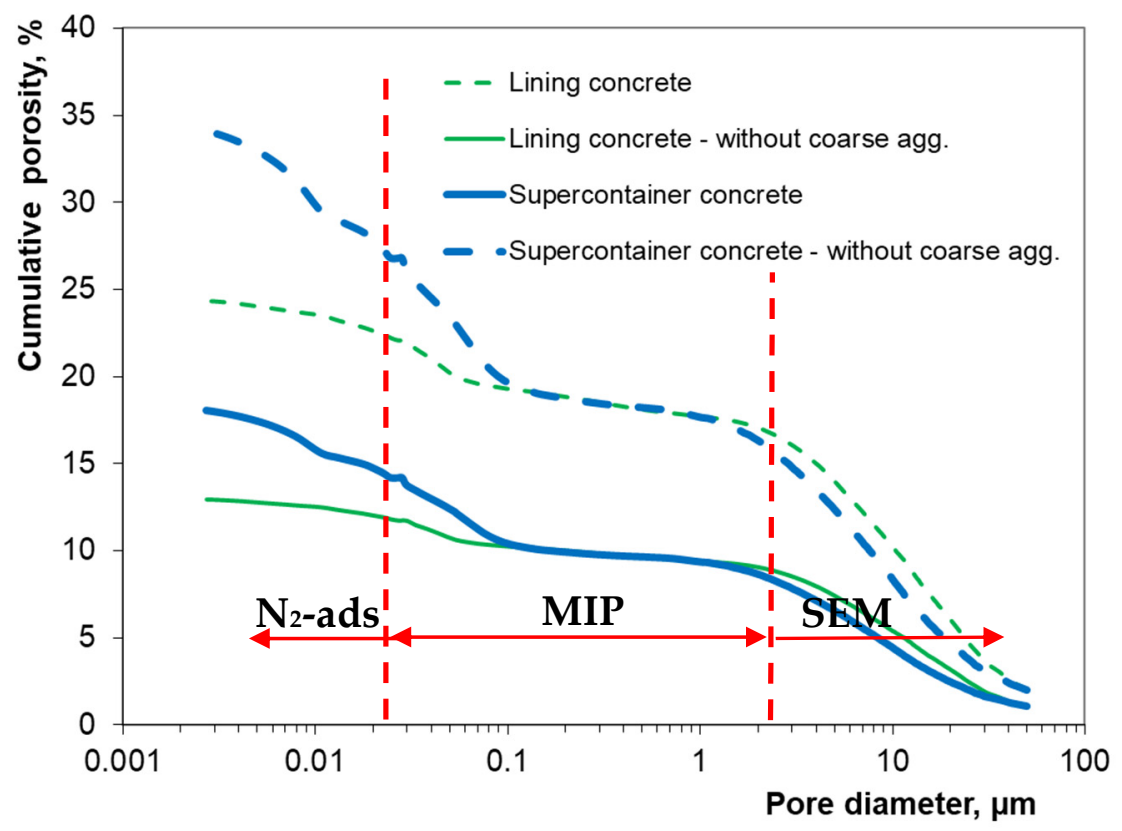

Figure 5. Pore size distribution for lining and supercontainer concrete, combined from $\mathrm{N}_{2}$ asdsorption, MIP and SEM measurements.

The cumulative porosity determined by combination of MIP, $\mathrm{N}_{2}$-adsorption and SEM of lining and supercontainer (including aggregates) is $13 \%$ and $18 \%$, respectively (Table 3). The measured water porosity also shows a higher value for supercontainer concrete. Though the water porosity is slightly lower than the cumulative porosity obtained by the combination of MIP, $\mathrm{N}_{2}$-adsorption and SEM for both lining and supercontainer concretes, it can still be considered that the accessible porosity estimated by these two methods are in line with each other as a slight difference could be within the uncertainty of measurements and combined (MIP, $\mathrm{N}_{2}$-adsorption and SEM) approach.

Table 3. Summary of measured properties.

\begin{tabular}{ccc}
\hline & Lining & Supercontainer \\
\hline Water porosity $(\%)$ & 11 & 14 \\
Cumulative porosity $(\%)$ & 13 & 18 \\
\hline
\end{tabular}

When looking in more detail at the pore size distribution, both materials have a similar distribution for pores between 0.1 to a few micrometers. However, the pore fraction in this range is quite limited (about $1 \%$ ). The lining concrete has a slightly coarser pore size in a range larger than a few micrometers compared to the supercontainer concrete, although the cumulative porosity in this range is quite similar, about $10 \%$. For smaller pores $(<0.1 \mu \mathrm{m})$, 
the two curves start deviating: for the lining, only $2.5 \%$ of its cumulative porosity can be found in pores $<0.1 \mu \mathrm{m}$, while this is $7.5 \%$ for the supercontainer. The larger porosity of the supercontainer can be almost fully attributed to a larger number of pores $<0.1 \mu \mathrm{m}$.

\subsection{Diffusion Coefficients}

The reported average diffusion coefficients in the lining and the supercontainer are for $\mathrm{He}, 2.5$ and $9.6 \times 10^{-11} \mathrm{~m}^{2} / \mathrm{s}$, respectively, and for $\mathrm{Ne}, 0.72$ and $1.8 \times 10^{-11} \mathrm{~m}^{2} / \mathrm{s}$, respectively (Table 4 ). The ratio of the average diffusion coefficient in the supercontainer vs. lining samples is 3.8 for $\mathrm{He}$ and 2.5 for $\mathrm{Ne}$, which shows that diffusion in the supercontainer samples is considerably faster than in the lining samples. Furthermore, the slight difference in the diffusion ratios of $\mathrm{He}$ and Ne measured on the supercontainer and lining samples illustrates that gas diffusion is not only dependent on the microstructure of the materials but also dependent the characteristics of the gas itself (e.g., molecular size).

Table 4. Overview of measured hydraulic conductivity and diffusivity of He and Ne on lining and supercontainer samples.

\begin{tabular}{ccccc}
\hline Samples & Cumulative Porosity (\%) & K (m/s) & He $\boldsymbol{D}_{\text {eff }}$ & Ne $\boldsymbol{D}_{\text {eff }}$ \\
\hline Lining 1 & \multirow{2}{*}{13} & $1.6 \times 10^{-14}$ & $2.4 \pm 0.1 \times 10^{-11}$ & $6.6 \pm 0.4 \times 10^{-12}$ \\
Lining 2 & & $1.3 \times 10^{-14}$ & $2.5 \pm 0.2 \times 10^{-11}$ & $7.7 \pm 0.6 \times 10^{-12}$ \\
Supercontainer 1 & \multirow{2}{*}{18} & $8.0 \times 10^{-13}$ & failed & failed \\
Supercontainer 2 & & $6.8 \times 10^{-13}$ & $12 \pm 0.3 \times 10^{-11}$ & $1.9 \pm 0.1 \times 10^{-11}$ \\
Supercontainer 3 & & $2.8 \times 10^{-13}$ & $7.1 \pm 0.4 \times 10^{-11}$ & $1.6 \pm 0.1 \times 10^{-11}$ \\
\hline
\end{tabular}

Note that for $\mathrm{CH}_{4}$, no trace was measured in the He vessel after 150 days, which indicates that the diffusion coefficient of $\mathrm{CH}_{4}$ is very low, or that the pore network is so narrow that $\mathrm{CH}_{4}$ cannot find a connected path. Typically, $D_{\text {eff }}$ is in these cases estimated to be lower than $1 \times 10^{-12} \mathrm{~m}^{2} / \mathrm{s}$. This value was obtained by performing a fit for a sample in which the concentration $\mathrm{CH}_{4}$ is still below $100 \mathrm{ppm}$ (detection limit of the GC) after 150 days. In this case, as an example, $D_{\text {eff }}$ would be $<1.3 \times 10^{-12} \mathrm{~m}^{2} / \mathrm{s}$. The results for ethane are similar: no ethane could be measured, even after 180 days and with a low detection limit of only 20 ppm.

Similar observations have been made in other materials. In cement-based "simple systems", Phung et al. [34] were not able to obtain diffusion coefficients for Xe. In Opalinus Clay [18], it was not possible to obtain diffusion coefficients for $\mathrm{CH}_{4}$, Xe and $\mathrm{C}_{2} \mathrm{H}_{6}$ and recently, no diffusion of Ar and $\mathrm{C}_{2} \mathrm{H}_{6}$ could be observed in a sample of the Souvré formation (thinly bedded laminated dark grey to black silicites ("phtanites"), or silicified shales and limestone, located in the Campine Basis) [35] (unpublished data). According to Jacops et al. [18], this behavior can be explained when considering a percolation transition: when the size of the diffusing molecule rises, fewer pores are available for the transport (diffusion) of that molecule. In a first stage, this will lead to longer travel paths ("tortuosity") since only pores with a pore size larger than the size of the diffusing molecule are available. When still increasing the molecular size, there is no longer a connected path (of pores available for transport) between the larger pores, and hence, the diffusion coefficient becomes nearly zero. Whether a system is prone to percolation transition problems or not is related to its porosity and pore size distribution. Typically, percolation transition problems have been observed up to now in samples with a porosity of circa $10 \%$ and less. Moreover, the smaller the pore size, the more likely problems will occur, but it is the smallest connecting pore in the diffusion path which dominates the process: when very narrow pores (few $\mathrm{nm}$ ) connect several bigger pores ( $\mu \mathrm{m}$ range), the average pore size is in the $\mu \mathrm{m}$ range, but a percolation transition problem can still occur. As there are many unknowns in this process, it is a subject of further investigation, in which porosity, pore size distribution and pore connectivity will be studied. 


\subsection{Correlation between Diffusion and Microstructures}

The pore size distribution can also explain the difference in diffusivity for the lining and supercontainer samples: the increase of the number of pores in the region $<0.1 \mu \mathrm{m}$ for the supercontainer concrete leads to a diffusivity that is three to four times higher for $\mathrm{Ne}$ and $\mathrm{He}$, respectively. This indicates that the pores $<0.1 \mu \mathrm{m}$ play an important role in the diffusion process.

Phung et al. [23] reported a correlation between the accessible porosity and the ratio $\frac{D_{e f f}}{D_{0}}\left(D_{0}\right.$ is the diffusion coefficient of a gas in free water) for different intact and altered cement-based samples and different diffusing gases. This relationship can be described with following exponential function with $\mathrm{x}=$ porosity:

$$
\frac{D_{e f f}}{D_{0}}=0.0003 e^{10.76 x}
$$

Applying Equation (5) to the supercontainer and lining materials shows two data points (purple dots) which differ by less than one order of magnitude from the measured values (red squares and green triangles) (Figure 6). At first sight, the exponential relation which was drafted for cement pastes can be used for concrete samples also. However, the difference in pore size distribution might significantly affect the diffusion behavior in concrete-based materials. The samples described in [23] show that the majority of the pores are smaller than $0.1 \mu \mathrm{m}$, while the samples in this work have $>50 \%$ of the cumulative porosity located in pores $>0.1 \mu \mathrm{m}$. This significant number of larger pores leads to an increased diffusivity. In order to account for the variability of samples and gases, a more comprehensive predictive model which takes into account the molecular size of diffusing species and the pore characteristics of concrete (i.e., porosity, constrictivity, tortuosity) was already developed and tested by [23]. This model is expressed as a set of three equations, Equation (6) to (8):

$$
\begin{gathered}
D_{e f f}=D_{0} \frac{\eta \delta}{\tau^{2}} \\
\delta=k_{1} e^{-k_{2}\left(\frac{d m}{d_{p}}\right)} \\
\tau^{2}=-1.5 \tanh \{8(\eta-0.25)\}+2.5
\end{gathered}
$$

where $\tau(-)$ and $\delta(-)$ are the tortuosity and constrictivity, respectively, which are usually considered as intrinsic properties of materials. $k_{1}$ and $k_{2}(-)$ are the fitting parameters, and $d_{m}(\mathrm{~nm})$ and $d_{p}(\mathrm{~nm})$ are the molecular diameter and the pore diameter of the concrete, respectively.

Figure 7 shows a comparison of the predicted diffusivity from the model and the measured ones (squares) from this study. The values of $k_{1}$ and $k_{2}$ for different porosities were calculated using exponential relationship fitted with data presented in [23], which are 16.7 and 11.6 for $k_{1}$ and $k_{2}$, respectively, for lining concrete, and 18.5 and 11.0 for $k_{1}$ and $k_{2}$, respectively, for supercontainer concrete. It can be seen that the predicted results (full line) are in quite good agreement with the measured ones (squares). Moreover, 86 percent of the measured diffusivity values fall within factor 2 bounds (differ within a factor of 2-indicated with dashed lines) compared to the predicted diffusivity, which is much improved compared to the exponential relationship shown in Figure 6.

\subsection{Permeability and Water Sorptivity}

It is expected that the diffusivity, water permeability and water sorptivity are well correlated, as they are also the transport properties of the concrete materials. The average water permeability and water sorptivity are summarized in Table 5 . The permeabilities of the supercontainer and lining concretes are in the order of $10^{-13}$ and $10^{-14} \mathrm{~m} / \mathrm{s}$, respectively, which is in the range of permeability for low permeable concrete. The ratio between the transport properties of supercontainer and lining concrete is also calculated. As expected, such a ratio is always larger than 1 for all transport properties, implying a 
consistency in transport properties due to the coarser microstructure of supercontainer compared to lining concrete. It is interesting to note that the microstructure of concrete significantly affects the water permeability, which results in a factor of 41.9 between the permeability of supercontainer and lining concretes. On the other hand, with a factor of 1.6, the influence of microstructure on water sorptivity is not significant. This is explained by the fact that the sorptivity is controlled by the capillary suction, which is mainly dominated by the pores with size larger than a few tens of nanometers. In this range, the microstructure is not much different between lining and supercontainer concretes as shown in Figure 5. For diffusion, the smaller pores also contribute to the transport of diffusing species. Therefore, with a significant higher pore volume for pores with size smaller than a few tens of nanometers, the ratio between the diffusivity of supercontainer and lining concrete is much higher than the one for water sorptivity (i.e., 2.5 and 3.8 for $\mathrm{Ne}$ and $\mathrm{He}$ diffusivity, respectively).

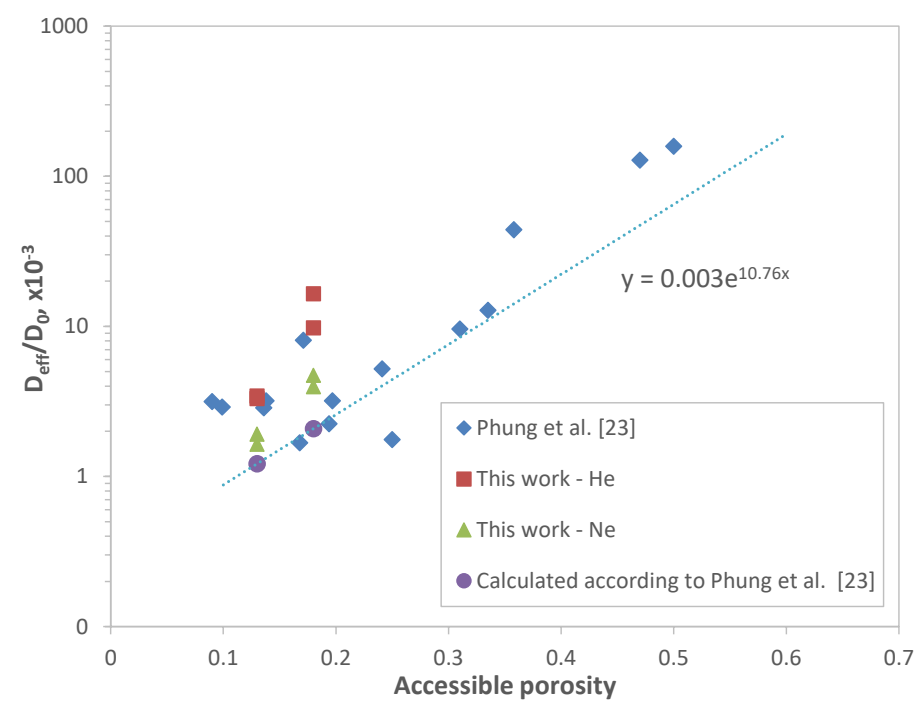

Figure 6. Comparison of relative diffusivity obtained from this work and literatures.

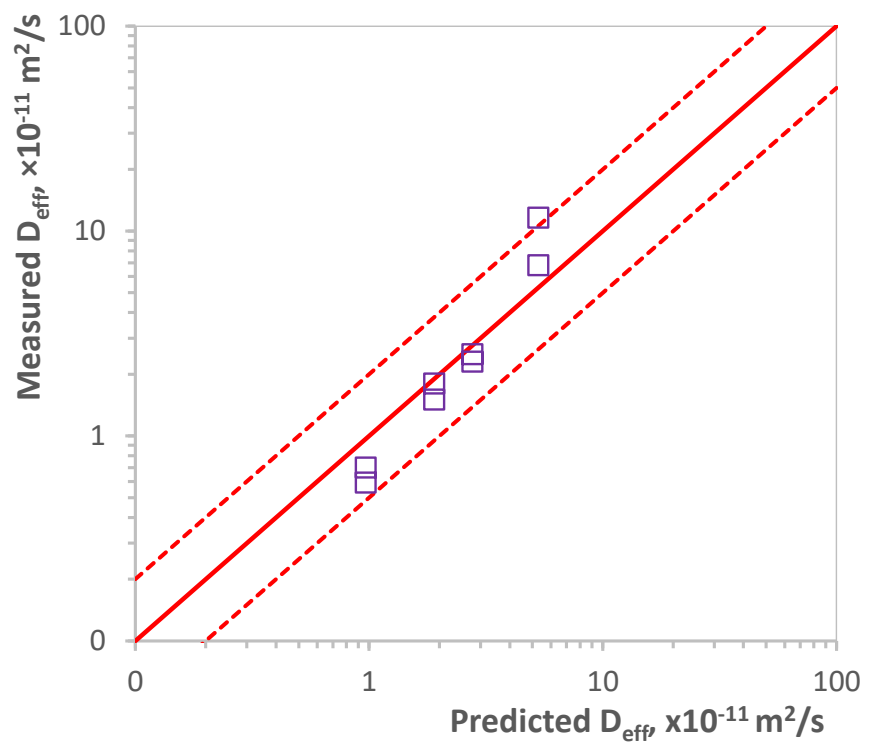

Figure 7. Comparison of measured diffusivity of this study (purple squares) and the predictive diffusivity using a model accounted for microstructural properties for concrete and the molecular diameters for diffusing species proposed by Phung et al. [23]. The full line indicates the model results while the dashed lines indicate the factor 2 bounds. 
Table 5. Water permeability, sorptivity and diffusivity of lining and supercontainer concretes.

\begin{tabular}{cccc}
\hline & Lining & Supercontainer & Ratio Supercontainer/Lining \\
\hline Average water permeability (m/s) & $1.4 \times 10^{-14}$ & $59 \times 10^{-14}$ & 41.9 \\
\hline Average water sorptivity (m/s $\mathrm{s}^{-1 / 2}$ ) & 0.034 & 0.056 & 1.6 \\
Average He diffusivity (m/s $)$ & $2.5 \times 10^{-11}$ & $9.6 \times 10^{-11}$ & 3.8 \\
Average Ne diffusivity (m/s $)$ & $0.72 \times 10^{-11}$ & $1.8 \times 10^{-11}$ & 2.5 \\
\hline
\end{tabular}

\section{Conclusions}

A series of experiments investigating the transport properties for two concrete engineered barrier materials (supercontainer and gallery lining) has been performed, providing water permeability values and diffusion coefficients for He and Ne. In addition, some microstructural properties have been measured, including the specific surface area, porosity, water sorptivity and pore size distribution. All transport properties are larger in the supercontainer samples than in the lining samples. The pore size distribution, combining data from $\mathrm{N}_{2}$-adsorption, MIP and SEM measurements, shows a cumulative porosity, which is $13 \%$ for the lining and $18 \%$ for the supercontainer. The increased porosity for the supercontainer is mainly attributed to a larger number of pores in the range $<0.1 \mu \mathrm{m}$. Two models which can be used to predict the diffusivity are investigated. The first model has been derived previously for cement-based materials and is an exponential model which uses porosity as input parameter. The difference between the measured and predicted data is less than one order of magnitude. In order to also account for difference in the pore network, a second model, accounting for the molecular size of the diffusing species and the pore characteristics (tortuosity, constrictivity, porosity) was used. The results showed that $86 \%$ of the measurements of the work fall within the factor 2-bound of the model, which indicates the good prediction capabilities of this model.

Author Contributions: Conceptualization, E.J. and Q.T.P.; methodology, E.J., Q.T.P. and L.F.; resources, S.L.; writing—original draft preparation, E.J., Q.T.P. and L.F.; writing-review and editing, S.L.; supervision, S.L.; project administration, E.J. All authors have read and agreed to the published version of the manuscript.

Funding: This research received no external funding.

Institutional Review Board Statement: Not applicable.

Informed Consent Statement: Not applicable.

Data Availability Statement: This study did not report any data.

Acknowledgments: The work presented herein has been performed in the broader framework of a public-public cooperation between ONDRAF/NIRAS and SCK CEN. The work was performed with the technical support of D. Verhaegen, T. Maes and A. Vanleeuw.

Conflicts of Interest: The authors declare no conflict of interest.

\section{References}

1. Yu, L.; Rogiers, B.; Gedeon, M.; Marivoet, J.; De Craen, M.; Mallants, D. A critical review of laboratory and in-situ hydraulic conductivity measurements for the Boom Clay in Belgium. Appl. Clay Sci. 2013, 75-76, 1-12. [CrossRef]

2. Maes, N.; Bruggeman, C.; Govaerts, J.; Martens, E.; Salah, S.; Van Gompel, M. A consistent phenomenological model for natural organic matter linked migration of Tc(IV), $\mathrm{Cm}(\mathrm{III}), \mathrm{Np}(\mathrm{IV}), \mathrm{Pu}(\mathrm{III} / \mathrm{IV})$ and $\mathrm{Pa}(\mathrm{V})$ in the Boom Clay. Phys. Chem. Earth Parts A/B/C 2011, 36, 1590-1599. [CrossRef]

3. Maes, N.; Salah, S.; Jacques, D.; Aertsens, M.; Van Gompel, M.; De Canniere, P.; Velitchkova, N. Retention of Cs in Boom Clay: Comparison of data from batch sorption tests and diffusion experiments on intact clay cores. Phys. Chem. Earth 2008, 33, S149-S155. [CrossRef]

4. Van Geet, M.; Bastiaens, W.; Ortiz, L. Self-sealing capacity of argillaceous rocks: Review of laboratory results obtained from the SELFRAC project. Phys. Chem. Earth Parts A/B/C 2008, 33 (Suppl. 1), S396-S406. [CrossRef]

5. ONDRAF/NIRAS. Research, Development and Demonstration (RDED) Plan, State-of-the-Art Report as of December 2012; NIROND-TR 2013-12 E; ONDRAF/NIRAS: Brussels, Belgium, 2013. 
6. ONDRAF/NIRAS. Design and Construction of the Geological Disposal Facility for Category B and Category C Wastes (V3); Technical Report NIROND-TR 2017-12 E V3; ONDRAF/NIRAS: Brussels, Belgium, 2020.

7. Van Geet, M.; Weetjens, E. Strategic Choices in the Belgian Supercontainer Design and Its Treatment in a Safety Case; Nuclear Energy Agency of the OECD (NEA): Paris, France, 2012; pp. 109-114.

8. Perko, J.; Weetjens, E. Thermohydraulic Analysis of Gas Generation in a Disposal Facility for Vitrified High-Level Radioactive Waste in Boom Clay. Nucl. Technol. 2011, 174, 401-410. [CrossRef]

9. Rodwell, W.; Harris, W.; Horseman, S.; Lalieux, P.; Müller, W.; Ortiz, L.; Pruess, K. Gas Migration and Two-Phase Flow through Engineered and Geological Barriers for a Deep Repository for Radioactive Waste; EUR19122; European Commission: Luxembourg, 1999.

10. Shaw, R.P. The Fate of Repository Gases (FORGE) project. In Gas Generation and Migration in Deep Geological Radioactive Waste Repositories; Geological Society London Special Publications: London, UK, 2015; Volume 415. [CrossRef]

11. Yu, L.; Weetjens, E. Summary of Gas Generation and Migration. Current State-of-the-Art; SCK-CEN ER-106: Mol, Belgium, 2009.

12. Capouet, M.; Noseck, U.; Navarro, M.; Rubel, A.P.; Van Luik, A.; Sillen, X. Relevance of Gases in the Post-Closure Safety Case: An IGSC Position Paper; Nuclear Energy Agency (NEA): Paris, France, 2015.

13. Jacops, E.; Wouters, K.; Volckaert, G.; Moors, H.; Maes, N.; Bruggeman, C.; Swennen, R.; Littke, R. Measuring the effective diffusion coefficient of dissolved hydrogen in saturated Boom Clay. Appl. Geochem. 2015, 61, 175-184. [CrossRef]

14. Jacops, E.; Volckaert, G.; Maes, N.; Weetjens, E.; Govaerts, J. Determination of gas diffusion coefficients in saturated porous media: He and $\mathrm{CH}_{4}$ diffusion in Boom Clay. Appl. Clay Sci. 2013, 83-84, 217-223. [CrossRef]

15. Jacops, E.; Maes, N.; Bruggeman, C.; Grade, A. Measuring diffusion coefficients of dissolved He and Ar in three potential clay host formations: Boom Clay, Callovo-Oxfordian Clay and Opalinus Clay. In Radioactive Waste Confinement: Clays in Natural and Engineered Barriers; Geological Society London Special Publications: London, UK, 2016; Volume 443. [CrossRef]

16. Jacops, E.; Aertsens, M.; Maes, N.; Bruggeman, C.; Krooss, B.M.; Amann-Hildenbrand, A.; Swennen, R.; Littke, R. Interplay of molecular size and pore network geometry on the diffusion of dissolved gases and HTO in Boom Clay. Appl. Geochem. 2017, 76, 182-195. [CrossRef]

17. Jacops, E. Development and Application of an Innovative Method for Studying the Diffusion of Dissolved Gases in Porous Saturated Media. Ph.D. Thesis, KU Leuven, Leuven, Belgium, 2018.

18. Jacops, E.; Aertsens, M.; Maes, N.; Bruggeman, C.; Swennen, R.; Krooss, B.; Amann-Hildenbrand, A.; Littke, R. The Dependency of Diffusion Coefficients and Geometric Factor on the Size of the Diffusing Molecule: Observations for Different Clay-Based Materials. Geofluids 2017, 2017, 16. [CrossRef]

19. Phung, Q.T.; Maes, N.; Jacques, D.; Bruneel, E.; Van Driessche, I.; Ye, G.; De Schutter, G. Effect of limestone fillers on microstructure and permeability due to carbonation of cement pastes under controlled CO2 pressure conditions. Constr. Build Mater. 2015, 82, 376-390. [CrossRef]

20. Phung, Q.T.; Maes, N.; Jacques, D.; De Schutter, G.; Ye, G. Investigation of the changes in microstructure and transport properties of leached cement pastes accounting for mix composition. Cem. Concr. Res. 2015, 79, 217-234. [CrossRef]

21. Faucon, P.; Adenot, F.; Jacquinot, J.F.; Petit, J.C.; Cabrillac, R.; Jorda, M. Long-term behaviour of cement pastes used for nuclear waste disposal: Review of physico-chemical mechanisms of water degradation. Cem. Concr. Res. 1998, 28, 847-857. [CrossRef]

22. Phung, Q.T. Effects of Carbonation and Calcium Leaching on Microstructure and Transport Properties of Cement Pastes. Doctoral Thesis, UGent-Universiteit Gent, Ghent, Belgium, 2015.

23. Phung, Q.T.; Maes, N.; Jacops, E.; Jacques, D.; De Schutter, G.; Ye, G. Insights and issues on the correlation between diffusion and microstructure of saturated cement pastes. Cem. Concr. Compos. 2019, 96, 106-117. [CrossRef]

24. Chen, G.; Dizier, A.; Li, X.; Verstricht, J.; Sillen, X.; Levasseur, S. Numerical Prediction of the Large-Scale in Situ PRACLAY Heater Test in the Boom Clay. Rock Mech. Rock Eng. 2021, 54, 2197-2218. [CrossRef]

25. Craeye, B. Early-Age Thermo-Mechanical Behaviour of Concrete Supercontainers for Radwaste Disposal. Doctoral Thesis, Ghent University, Ghent, Belgium, 2010.

26. Phung, Q.T.; Gaboreau, S.; Maes, N.; Claret, F. Preliminary experimental results on the changes in microstructure, mineralogy and transport properties of Boom Clay-concrete interface. In Proceedings of the Second Workshop of the HORIZON 2020 CEBAMA Project (KIT Scientific Reports; 7752); KIT Scientific Publishing: Karlsruhe, Germany, 2020; p. 75.

27. Minasny, B.; Cook, F. Sorptivity of Soils. In Encyclopedia of Agrophysics; Gliński, J., Horabik, J., Lipiec, J., Eds.; Springer: Dordrecht, The Netherlands, 2011; pp. 824-826.

28. Washburn, E.W. Note on a Method of Determining the Distribution of Pore Sizes in a Porous Material. Proc. Natl. Acad. Sci. USA 1921, 7, 115-116. [CrossRef] [PubMed]

29. Brunauer, S.; Emmett, P.H.; Teller, E. Adsorption of Gases in Multimolecular Layers. J. Am. Chem. Soc. 1938, 60, 309-319. [CrossRef]

30. Barrett, E.P.; Joyner, L.G.; Halenda, P.P. The determination of pore volume and area distributions in porous substances. I. Computations from nitrogen isotherms. J. Am. Chem. Soc. 1951, 73, 373-380. [CrossRef]

31. Dubinin, M.M.; Astakhov, V.A. Development of the concepts of volume filling of micropores in the adsorption of gases and vapors by microporous adsorbents. Bull. Acad. Sci. UssrDiv. Chem. Sci. 1971, 20, 3-7. [CrossRef]

32. Phung, Q.T.; Maes, N.; Jacques, D. Application of Multiple Techniques to Quantify Pore Structure of Degraded Cementitious Materials. In Proceedings of the XIV DBMC 14th International Conference on Durability of Building Materials and Components, Ghent, Belgium, 29-31 May 2017; p. 12. 
33. Thommes, M.; Kaneko, K.; Neimark, A.V.; Olivier, J.P.; Rodriguez-Reinoso, F.; Rouquerol, J.; Sing, K.S. Physisorption of gases, with special reference to the evaluation of surface area and pore size distribution (IUPAC Technical Report). Pure Appl. Chem. 2015, 87, 1051-1069. [CrossRef]

34. Phung, Q.T.; Maes, N.; Jacops, E. Diffusion of dissolved gases in saturated cementitious materials: Does the size matter? In Proceedings of the 15th International Congress on the Chemistry of Cement, Prague, Czech Republic, 16-20 September 2019.

35. Qiu, X.; Chen, J.; Deprez, M.; Cnudde, V.; Ye, G.; De Schutter, G. 3D Microstructure Simulation of Reactive Aggregate in Concrete from 2D Images as the Basis for ASR Simulation. Materials 2021, 14, 2908. [CrossRef] [PubMed] 